Vol. 13 , No. 1

ISSN: 2085 - 4609 (Print), e- ISSN 2656-0208

Journal homepage: bit.ly/UltimaComm

The Dynamics of Communal Participatory Communication in the Anticipation of COVID-19 Pandemic on WhatsApp Group Media

\title{
Dwi Kartikawati
}

To cite this article:

Kartikawati, D. (2021). The Dynamics of Communal Participatory Communication in the Anticipation of COVID19 Pandemic on WhatsApp Group Media, Ultimacomm, 13(1), 65-81.

https://doi.org/https://doi.org/10.31937/ultimacomm.v13i1.1941

Ultimacomm publishes research articles and conceptual paper in the field of communication, mainly digital journalism and strategic communication. It is published twice a year by the Faculty of Communication of Universitas Multimedia Nusantara

Submit your article to this journal [

Published in Partnership with

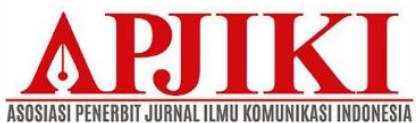

Full Terms \& Conditions of access and use can be found at http://ejournals.umn.ac.id/index.php/FIKOM/about 


\title{
The Dynamics of Communal Participatory Communication to Anticipate COVID-19 Pandemic on WhatsApp Group Media
}

\section{Dwi Kartikawati}

Universitas Nasional

Email: dookartika@yahoo.com

Received Feb. 8, 2021; Revised Apr. 3, 2021; Accepted Apr. 30, 2021

\begin{abstract}
The research aimed to find communal participatory communication through WhatsApp group media at the Neighbourhood Association (Rukun Tetangga or RT) level in the Pasar Minggu Jakarta area in anticipation of the dangers of Covid-19. The struggle against the pandemic is not only carried out by the government but also by the average Indonesians. Therefore, to anticipate the dangers of Covid-19, the role of the Neighbourhood Association administrators as the agent of the government's efforts to prevent the spread of Covid-19 is essential. Participatory communication provides a space for people to exchange information and knowledge. By utilising WhatsApp media, virtual public spaces can be created to establish useful participatory communication. The theoretical framework used in this study is participatory communication, the concept of dynamics, WhatsApp communication media, and the virtual public sphere. This research was qualitative research with a case study method. The results showed that communal participatory communication carried out through WhatsApp groups in preventing the spread of Covid-19 is based on four components, namely heteroglossia, dialogic, polyphony, and carnival. Meanwhile, the typology of participation patterns in citizen communication through WhatsApp is the Co-management pattern involving the community in managing COVID-19 prevention efforts. Communal participatory communication has one common goal, namely to carry out health development in the neighbourhood. This effort makes residents continue to comply with health protocols and ensure the safety of their families and residents. After all, Covid19 is not only a matter of the dangers of the virus but is related to a more complex social situation, namely the economic resilience of the residents.
\end{abstract}

Keywords: Participatory Communication, Social Media, WhatsApp

\section{INTRODUCTION}

On 30 January 2020, WHO declared a Public Health Emergency of International Concern (PHEIC) (Kementerian Kesehatan, 2020). This determination was followed by the WHO's novel Coronavirus in humans called Coronavirus Disease (Covid-19) on 12 February 2020. Covid-19 is caused by SARS-COV2, which is included in the large family of coronaviruses. This disease is caused by a similar virus that also caused the SARS pandemic in 2003. The symptoms of Covid19 are similar to those of SARS. However, the SARS death rate (9.6\%) 
was higher than Covid-19 (currently less than 5\%). Even so, the number of Covid-19 cases is far more than SARS (Kementerian Kesehatan, 2020). The spread of Covid-19 is also wider and faster than SARS. The Covid-19 pandemic has had a tremendous impact, not only in terms of health but also in various other sectors of life. The struggle against this pandemic does belong to not only the government but also the responsibility of all Indonesian people. So, to anticipate the transmission of Covid-19, the Neighbourhood Association or Rukun Tetangga (RT) managements are an agent of the government's efforts in overcoming and preventing the spread of the Covid-19 virus becomes important.

Neighbourhood Association or Rukun Tetangga (RT) is a social organisation with a privilege, namely proximity to the community. According to the Regulation of the Minister of Home Affairs of Indonesia Number 5 of 2007 concerning Guidelines for Structuring Social Institutions, Neighbourhood Association is an institution formed through local community consultations in the context of government services to the community that has been determined by the Sub-district administration or Head of sub-district (Kementrian Dalam Negeri Republik Indonesia, 2017). Neighbourhood Associations are led by a Head whom the residents in the neighbourhood elect. Furthermore, the Neighbourhood Association was formed to increase the community's role, service, welfare, and participation (Kementrian Dalam Negeri Republik Indonesia, 2017).

Socialisation and participation about the importance of maintaining social distance and implementing social restrictions to the community within the Neighbourhood Association are crucial to prevent the spread of the virus. For this reason, participation and socialisation activities during the Covid-19 pandemic are carried out using WhatsApp Media. WhatsApp is one of the social medias that is currently widely used to benefit socialising and deliver messages both by individuals and groups.

WhatsApp is the most widely used instant messaging application worldwide (Bafadhal, 2017). In Indonesia, there are about 58\% of mobile phone users who use the WhatsApp messenger application. Then, WhatsApp can effectively facilitate various social activities of a person, be it individuals, groups, families, or professionals. WhatsApp is a social media whose users can produce independent content. WhatsApp can also help establish relationships with other people. Indeed, web and mobile-based technologies can create interactive platforms where users can create, modify and share content, as well as maintain dialogue (Malka et al., 2015).

Communication through WhatsApp involves participatory communication from all levels of society. Communication is an important activity. In fact, communication is the basis for being able to interact with other people. So, communication is an important activity that is always carried out by each individual to obtain information and achieve goals (Kartikawati, D. Rajagukguk, D L, Sriwartini, 2019). Participation is active involvement in problem identification, solution development, and strategy implementation. According to Soleha (2017, p. 113), there are four indicators in communication: a) heteroglossia, b) dialogic, c) polyphony, d) carnival.

Through the application of participatory communication, the process of delivering messages involving residents is an integral part of efforts to prevent the spread of Covid19. This is because participatory communication provides space for people to exchange 
information and knowledge. Furthermore, the dynamics of participatory communication is more centred on the creation of shared meaning which focuses on achieving consensus or agreement (Syahyuti, 2006, p. 192). Participatory communication has several elements, namely freedom, equal rights, and equal access. In the participatory communication paradigm, communication is meaningful as a message shift focusing on informing and persuading behaviour change to provide facilities for the community and government to determine problems. The application of participatory communication not only facilitates the interests of the community in obtaining information but also becomes a medium to raise public awareness so that they have strength in dealing with problems related to efforts to prevent the spread of Covid-19. During the pandemic, the involvement of residents in establishing participatory communication was carried out by utilising the WhatsApp group media.

As one of the medias used, WhatsApp is one of the collective participatory media. In the context of being a collective participation medium, WhatsApp is used to share and exchange information, ideas, and experiences and develop relationships and form communities. The way of communicating in the context of collective participation media is considered a participatory culture. According to Murwani (2017), participatory communication culture are, 1) Affiliation - formal and informal membership in online groups or communities such as Facebook, Twitter, or mailing lists; 2) Expression generating new creative forms such as fan fiction; 3) Collaborative Problem Solving working together formally and informally to complete assignments and develop new knowledge (e.g. via Wikipedia); 4) Circulation - shaping media streams (like podcasting or bogging). Through WhatsApp media, a public space or public sphere is created that is needed as a medium for residents to interact and communicate. In this public space, individuals can develop themselves and are involved in exchanging directions and goals of existing residents.

Several studies that examine the pattern of participatory communication academically include research by Risyart A. Far Far entitled "Participatory Communication in the Implementation of Prima Tani in Sungai Kakap District, Pontianak Regency." This paper was published in the Scientific Journal of Agribusiness and Fisheries (Agrikan UMMUTernate) Volume 4 Issue 1 in 2011 using a quantitative survey approach. This research shows that Participatory Communication in the implementation of Prima Tani has proven effective in increasing farmers' knowledge and attitudes towards the integrated farming model (Far Far, 2011). In addition, Mutia Dewi \& Noer Ayufika Nulul's research entitled "Industrial Community Participatory Communication in Supporting Madiun City Branding" (2018) also shows that the Madiun Industrial Community participates in supporting branding through implementation and utilisation of results. This study also identifies forms of participatory communication in the industrial community in Madiun (Dewi \& Nulul, 2018).

However, this latest research is very different and is expected to contribute to the field of communication science because this research examines the communication side of participation. This study also relates the findings to the concept of the public sphere, where public space is created in the WhatsApp medium. The urgency in this study is to look at the dynamics of citizen involvement in establishing participatory communication 
that will support the government's efforts in the COVID-19 crisis by utilising WhatsApp group media that encourages the creation of the Public Sphere. This research was conducted on the WhatsApp group of residents at the Ministry of Health Complex, Pasar Minggu Jakarta. This complex area is one of the green zones in cases of Covid-19 transmission. The green zone is where there are no Coronavirus cases in the neighbourhood association area. In this housing complex, the scenario for controlling the spread of the Coronavirus is carried out through active surveillance, testing all suspects, and monitoring cases regularly and periodically. Based on this brief explanation, this latest research examined the dynamics of community participatory communication in anticipating the dangers of the Covid-19 virus through WhatsApp groups?

The concept of participatory communication was originated from the thoughts of Latin American intellectuals, especially Paulo Freire, who was followed by Luis Ramiro Beltra and Juan Diaz Bordenave. The term 'Participatory Communication' was first used officially in a seminar in Latin America sponsored by the Centre for Advanced Studies and Research for Latin America (Sutowo, 2020). Participatory communication emphasises community participation so that they have the opportunity and ability to express their aspirations in the policymaking process in their environment. The general characteristics of participatory communication are (Sinaga et al., 2016):

1. The community is the main actor who is dynamic and active in the process of social change that occurs

2. The communication process is adapted to a particular community or social group

3. Community-based dialogue is intended to help identify, and define the difference between felt needs and real needs

4. Communication is the right of the people

5. The process to achieve deep understanding and awareness of social reality, problems, and solutions.

There are four indicators in participatory communication (Soleha, 2017, p. 113), namely

a. Heteroglossia which can be interpreted that the development system is based on different groups that complement each other

b. Dialogue which means that group members know and respect each other as autonomous individuals and each has the right to voice

c. Polyphony which is the highest form of a dialogue in which disjointed voices increase to be open, clarify each other, and are given space

d. Carnival, which accommodates informal or casual language and communication styles that are in accordance with the existing habits of the community.

Meanwhile, the typology of how to implement participation in communication that occurs in the community is divided into three things, namely (Shery Arstein, 2013):

1. Non-participation, which is a pattern that places one party as a passive party 
2. Controlled participation which is a pattern of participation, in terms of This is controlled by another party. Controlled participation is further divided into two, namely limited participation, which allows the community to participate but is still limited by the authorities and manipulated participation which occurs in disguise and adapts the community so that it remains in accordance with the interests of the power holder

3. Power participation which is a participation pattern that is carried out democratically and facilitate the community as an autonomous entity. Power participation is further divided into several derivative patterns, namely comanagement and self-management. The co-management pattern is carried out by involving the community together in managing the existing development. In addition, the community is also invited in the process of making the established policies. Therefore, this pattern views the community as a development partner. On the other hand, the self-management pattern is the most advanced type of power participation. In self-management, the community is directly involved in the entire development process, including policymaking.

WhatsApp is an internet-based social media application that is one of the most popular results of the development of information technology. This internet-based application has the potential to be used as a communication medium because it makes it easier for users to communicate with each other and interact without spending much money. After all, WhatsApp does not use credit but internet data (Rahartri, 2019). According to Citra (2018), there are five reasons why Indonesians prefer WhatsApp over other media:

1. WhatsApp is a simple chat application and does not require a password

2. WhatsApp can be connected directly with cell phone contacts. By simply saving the phone number, the user can synchronise with the contacts of other users. As a result, users do not need to exchange IDs or PINs before they can communicate. WhatsApp can be a convenient and timely replacement for SMS for sending messages and also not a medium for 'stalking.'

3. WhatsApp has a simple interface and focuses on the chat function. Although there is a feature for 'status' updates, this feature is not used as a place to boast between fellow WhatsApp users. The emergence of the status update feature does not reduce the user's focus on its primary function, which is to send short messages. This reason makes the WhatsApp application more preferred because it is not a medium for 'stalking' between users

4. WhatsApp interface is straightforward, easy to understand, and saves internet data. WhatsApp has an advantage over other chat applications, namely an easyto-understand and straightforward interface, so even new users can easily understand the use of this application. The WhatsApp application can be said to be very light because it does not load many images, saves battery, and saves internet data 
5. WhatsApp application is free and has no ads. WhatsApp can be used for free throughout the year and does not display any ads. This makes WhatsApp the most convenient chat application to use compared to other chat applications.

In WhatsApp media, there are various features, including a 'Gallery' for adding photos, 'Contacts' for inserting contacts, a 'Camera' for taking pictures, an 'Audio' for sending voice messages, 'Maps' for sending map coordinates, and even 'Document' for inserting files. All features can be instantly delivered through this free application. These various features certainly add to the ease and convenience of communicating through online media (Rahartri, 2019).

The concept of the public sphere emerged from the work of Jurgen Habermas entitled "The Structural Transformation of the Public Sphere: An Inquiry into a Category of Gourgeois Society," which was published in 1989. The concept of public space is normatively defined as an arena of social life, where people can gather together and freely indicate and discuss various forms of social problems (Widyawati et al., 2011). In this public space, individuals are able to develop themselves and are involved in the exchange of community directions and goals. Habermas describes public space in three critical domains (Jati, 2016), namely

1. Public space as an arena which means that public space provides a basis or place for people to communicate in it

2. Public space is the public itself which indicates that the public has a vital role in realising democracy from the grassroots level

3. The public sphere is an agent, which means that a public sphere is an essential tool in conveying aspirations from the grassroots.

Furthermore, the public sphere is "every individual who comes to the public sphere is allowed to have an opinion on issues concerning the private or public area. In this condition, the public sphere has the primary role as a driver for the communication ability of each level of society" (Prasutomo et al., 2019).

In its development, public space is not only physical and can be sensed. The left of the public space has developed in the non-physical space and cannot be sensed directly by humans. Even so, public space can still be felt and witnessed as a reality. Furthermore, Habermas also revealed that along with the development of technology and communication, public space had penetrated virtual media, better known as cyberspace. This cyberspace basically provides a new public space or virtual public space, a virtual public space available on social media. Public space is now present in cyberspace and forms a communication space in it.

Meanwhile, virtual public space is the second and virtual public space that is used as an alternative or substitute for the first public space or real public space. Virtual public space is a public space that is artificial; it can mean that it is broader, free and open by utilising the internet network in cyberspace. One form of virtual public space that can be formed 
in cyberspace is a virtual public space in WhatsApp social media. WhatsApp's virtual public space allows the free and open exchange of various information and public opinions, especially regarding the prevention of Covid-19. Virtual public spaces allow individuals to have conversations or arguments with other individuals that can transcend geographical boundaries.

Dynamics means strength. Dynamics is the behaviour of one person to another that influences each other reciprocally. In dynamics, there is interaction and connectedness between one group and another as a whole (Santoso, 2004, p. 12).

\section{METHOD}

The current research uses a qualitative approach. This qualitative research approach is intended for researchers to gain an in-depth and detailed understanding of the problem under study. Qualitative research is research conducted in certain settings, which exist in real life (scientific) to investigate and understand the phenomena that occur, the reasons for their occurrence, and how they occur. Qualitative research is based on the concept of 'going exploring,' which involves a Case-Oriented Study of several cases or single cases (Gunawan, 2016, p. 83).

The research method used in this study is a case study, a research method that uses various data sources that can be used to systematically research, describe, and explain various aspects of an individual, group, program, organisation, or event. Data collection is the most strategic step for this research because the main goal is to get data. To get maximum interview results, the authors use several informants and one key informant. Informants are the designation for samples from qualitative research. The sample in qualitative research is not called the respondent but the resource person or participant.

Furthermore, interviews were conducted by direct interviews with key informants, namely the Head of the neighbourhood association of the MOH Complex, 3 other informants, namely the WhatsApp Group admin for the $\mathrm{MOH}$ Complex, and 2 residents of the $\mathrm{MOH}$ Complex. In this study, the resource person also acts as a provider of the necessary data and information. Then, observations were made by going directly into the field by observing and noting several things that the authors encountered and deemed sufficient to be able to collect the required data. During the research, the author entered as a member of the Covid-19 Coordination Group at the neighbourhood association level being studied. In the observation activity, the writer acts as Participant Observation. Participant observation is defined as a field strategy that simultaneously searches for the documents used, interviewing informants, making observations, participating and direct involvement, and introspection (Gunawan, 2016). Document studies are also carried out by the author as a supporting aspect of research when the data obtained in the field is lacking. The data collection technique can be seen in Figure 1. 
Figure 1. Research data collection

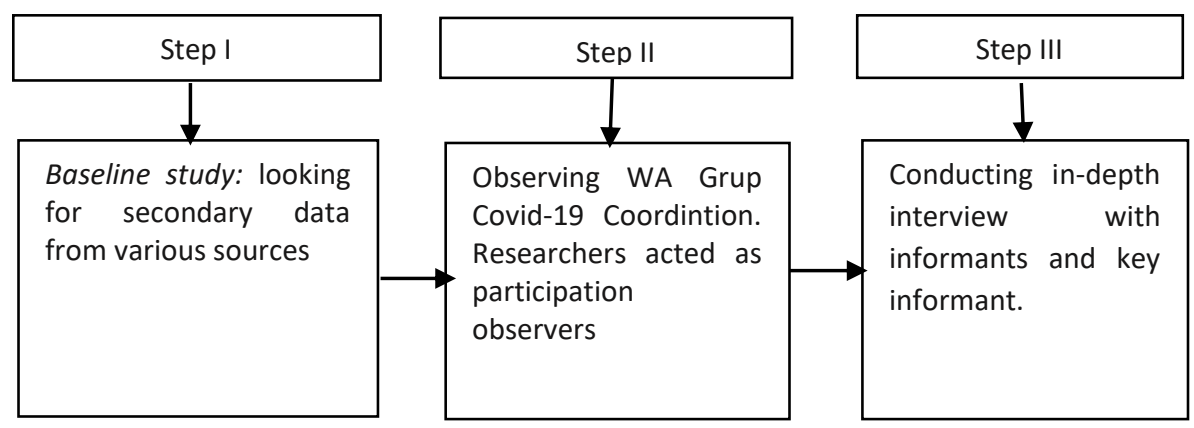

The data analysis techniques used in this study are (Sugiyono, 2007):

1. Data reduction with the process of selecting, concentrating, and paying attention to the simplification of data that emerges from field notes

2. Presentation of data in the form of a structured set of information that gives the possibility of drawing conclusions and taking action

3. Drawing conclusions in the form of a process of drawing and verifying the final conclusion which depends on the size of the collection of field notes, coding, storage, and retrieval methods used. In this study, the data validity technique used was triangulation. Triangulation can be done by checking data from various sources in various ways and at various times. The author compared the observation data with the interview data obtained and then makes a meaningful conclusion. The author also compares the data from the main informant or key informant with information from other secondary informants

\section{RESULTS \& DISCUSSION}

The results of this study are organised into three parts: WhatsApp group profiles, typology of participation forms of WhatsApp group members, and communal participatory communication.

The WhatsApp groups studied in this study are virtual and consist of residents who live in the Pasar Minggu Health Department Complex, South Jakarta. This WhatsApp group was formed to follow the residents' alertness to the COVID-19 pandemic at the neighbourhood association level. This group is a form of self-empowerment with a community group system based on the Neighbourhood association in forming a citizen communication system. The Head of the neighbourhood association 01 RW 07 in the Pasar Minggu Department Complex is the group leader. Furthermore, this group functions to unite steps to anticipate and follow up on all developments regarding the spread of Covid-19. It is hoped that this group will be able to explain unclear information and convey the latest situation regarding the development of the virus in the local neighbourhood association. This group consists of 53 participants representing residents from each house in the Pasar Minggu Health Department Complex. Figure 2 presents the group interface. 
Figure 2. WhatsApp Group Coordination Covid-19 Interface

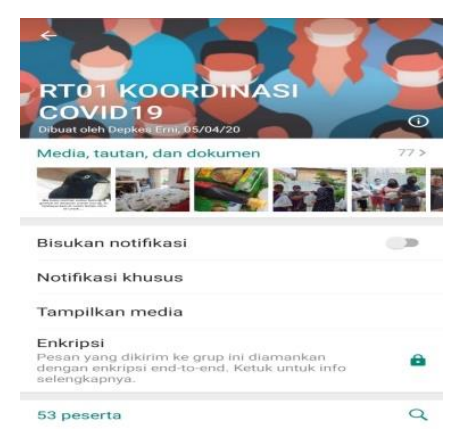

The purpose of the formation of a WhatsApp group based on the explanation of critical informants, among others, is establishing a citizen communication system, establishing a task force and person in charge of the field, issuing regulations for the safety of residents, ensuring communication is carried out to all residents, ensuring communication with residents with the status of people without Covid-19 symptoms, and in the supervision of Covid-19, not to embarrass people with Covid-19, and prevent the emergence of social stigma.

Furthermore, the key informant explained that the form of communication in coordinating essential steps to prevent the spread of the Covid-19 virus was that the neighbourhood association formally gave an official letter containing several steps that needed to be taken to curb the spread of the Covid-19 virus in the environment. This formal letter shows the level of urgency that symbolises that the Covid-19 issue is getting more and more official attention, especially regarding the coordination of the task force structure at the neighbourhood association or neighbourhood council and sub-district level. In the implementation in the field, the neighbourhood association carried out manual socialisation by installing several warnings in the form of posters or billboards containing PSBB (Large-Scale Social Restrictions) points, calls for maintaining health and cleanliness, 14-day quarantine rules, as well as prohibitions on gathering and restrictions road access. Then, online, the neighbourhood association formed two WhatsApp groups, namely 'Task Force Coordination' and 'Residents Coordination.' The 'Task Force Coordination' group discussed more strategic issues regarding COVID-19, especially before being disseminated to a wider group of residents. The last is the interpersonal communication approach, namely by meeting with residents directly and informally, without being arranged and not in groups. In addition, when meeting other residents, the neighbourhood association administrator shared the development of the environmental situation and programs related to Covid-19 in the neighbourhood.

In the context of the communication that takes place in the WhatsApp group, The Head of the neighbourhood association is a communicator who provides information 
transparently to all residents, including information about procedures for dealing with COVID-19, quarantine measures, to the provision of food or other logistics. In terms of conveying information and convincing residents of the dangers of Covid-19, neighbourhood association administrators always use official information from the subdistricts in the form of official letters, e-brochure leaflets, or WhatsApp posts from the sub-district. This official information will be forwarded or reported back to the citizen level.

Official information is more convincing than free posts from various social media sources. Therefore, one of the tasks of the neighbourhood association management and the task force is to check and re-check to ensure that information is true and not a hoax. Another approach is Conditioning, which is to build a psychological situation that the environment is in an emergency. This approach is carried out by installing several 'tools' in the form of warning posters and closing several access roads. With this unusual change, residents will feel that there is an urgency that must be considered.

During the Large-Scale Social Restrictions (PSBB) period in Jakarta, residents are expected to comply with the protocols contained in the PSBB, especially regarding the principles of family health and safety. On the other hand, residents are also expected to understand that COVID-19 is a matter of the dangers of the virus and affects more complex social situations, one of which is the economic resilience of residents around the complex. The management also hopes that residents report the condition of their families or people who live at home in a transparent manner. The report concerns the status of illness, OTG (Asymptomatic People), ODP (People Under Supervision), PDP (Patients Under Surveillance), Suspect or Positive. By means of transparent reporting, data to the task force and above (neighbourhood council and sub-district) will be easier and more accurate.

From the results of observations and interviews conducted by researchers, it was found that the typology of the forms of participation of WhatsApp group members includes the Power Participation pattern. Power Participation is a pattern of participation that is carried out democratically and facilitates the community as autonomous. In addition, it is also observed that there is a pattern of Co-management carried out by involving the community together in the management of development. In the Co-management pattern, the community continues to update the health conditions of their families and actively report them. If there are some unusual conditions, the admin will immediately provide a quick response for further follow-up. The key informant explained that even though participation in Co-management took place, there were obstacles experienced in using WhatsApp groups. If there is a problem, The Head of the neighbourhood association will directly contact the residents who are experiencing problems and ask about the reasons and conditions of the residents concerned. The residents are then 
invited to share information or updates directly. The admin also encourages residents to continue to update conditions by showing who has and has not updated. If residents do not want to join the WhatsApp group, the neighbourhood association will ask other family members, even household assistants, to update directly to the group.

The Heteroglossia indicator is the concept that the development system should accommodate different groups and communities so that they complement each other and work synergistically. For example, the diversity of groups in WhatsApp groups is that although there are various age differences (all members are adults), occupations, cultures, and others, they have one common goal, namely to carry out health development in the neighbourhood association area on an ongoing basis to prevent Covid19.

Meanwhile, the dialogical indicators include interactions that occur within the WhatsApp group as a whole. The meaning of the dialogical indicator is, of course, knowing and respecting other voices as subjects, no longer just as objects of communication in the process of preventing the danger of Covid-19. Residents can express opinions, participate in interacting by asking questions, and submitting their opinions and complaints. In the end, if there is a problem, a solution will be found together.

In the polyphony indicator, which is an advanced form of dialogue, residents can provide opinions, input without any intervention, without any emphasis on one view over another, and there is no dominance in conveying ideas, suggestions and criticism. So polyphony is an ideal form of participatory communication because the various diversity that exists is realised and then combined collectively to strengthen each other.

The carnival indicator on participatory communication is that the communication that occurs takes place in informal situations. WhatsApp group members are encouraged to participate in the carnival freely. So, this indicator is an effort to create a sense of kinship and brotherhood together by being aware of the situation around residents and immediately reporting things that are felt to be dangerous to the environment, especially related to the development of Covid-19. For example, in the housing complex that is the subject of the study, there is a connecting door with residents next to the complex, which is prone to be used for traffic by non-residents. So, this door is always locked. However, sometimes according to informant 1 , the door could suddenly open. If this happens, residents will immediately report to the neighbourhood association officials via telephone or WhatsApp group media. 
Table 1. Forms of messages and communication goals of coordination as a form of mutual concern

\begin{tabular}{|c|c|c|c|c|}
\hline No & Message Content & Purpose & Example of WA Screenshot & Themes/issues \\
\hline 1. & $\begin{array}{l}\text { Daily Health Report } \\
\text { from each home or } \\
\text { family representative. } \\
\text { For example, the } \\
\text { condition of each } \\
\text { resident living in one } \\
\text { house is reported in } \\
\text { full }\end{array}$ & $\begin{array}{l}\text { To note that the } \\
\text { initial conditions of } \\
\text { all residents are in a } \\
\text { safe and healthy } \\
\text { condition }\end{array}$ & 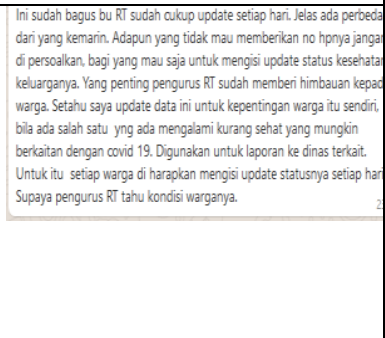 & Health \\
\hline 2. & $\begin{array}{l}\text { Health report for } \\
\text { people who are sick or } \\
\text { unwell } \\
\text { For example, reports } \\
\text { on the condition of } \\
\text { sick residents, } \\
\text { mentioning what } \\
\text { illness, for example, } \\
\text { fever, have been to } \\
\text { the doctor or not, and } \\
\text { others. }\end{array}$ & $\begin{array}{l}\text { Conditions are } \\
\text { known early to be } \\
\text { anticipated }\end{array}$ & 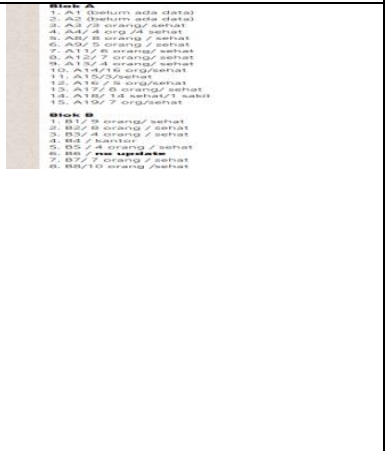 & Health \\
\hline 3 & 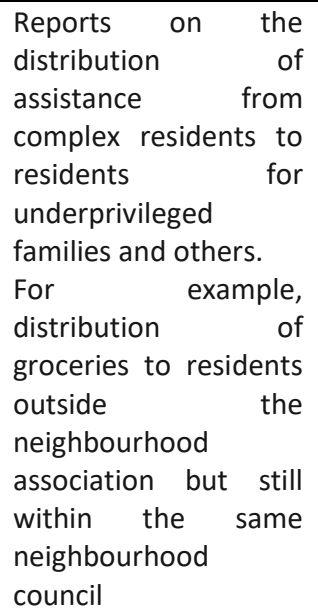 & $\begin{array}{l}\text { As a social safety net } \\
\text { for affected residents }\end{array}$ & 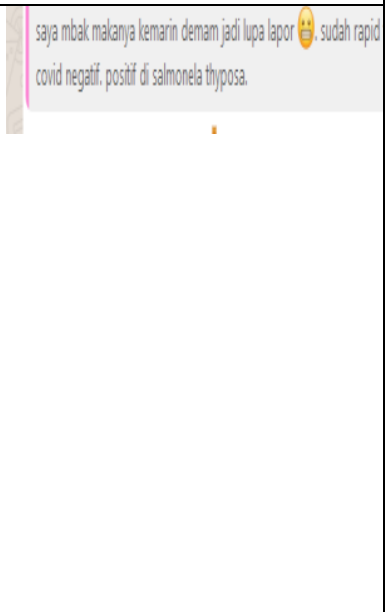 & $\begin{array}{l}\text { Providing social } \\
\text { assistance }\end{array}$ \\
\hline 4. & $\begin{array}{l}\text { Reports of disease } \\
\text { conditions other than } \\
\text { Covid-19, such as } \\
\text { dengue fever which is } \\
\text { no less dangerous } \\
\text { than Covid19 } \\
\text { For example, reports } \\
\text { of residents' illness } \\
\text { conditions, including } \\
\text { dengue fever, typhus, } \\
\text { and others. }\end{array}$ & $\begin{array}{l}\text { To know and } \\
\text { anticipate next steps, } \\
\text { such as fogging, etc }\end{array}$ & 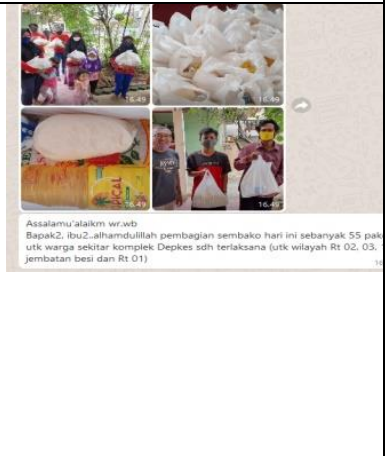 & Health \\
\hline
\end{tabular}




\begin{tabular}{|c|c|c|c|c|}
\hline 5. & $\begin{array}{l}\text { Sharing information } \\
\text { on anticipating stress } \\
\text { handling in the face of } \\
\text { a pandemic. } \\
\text { For example, } \\
\text { providing files and } \\
\text { videos about tips to } \\
\text { cheer up, etc }\end{array}$ & $\begin{array}{l}\text { For education on the } \\
\text { mental health of } \\
\text { residents during PSBB }\end{array}$ & 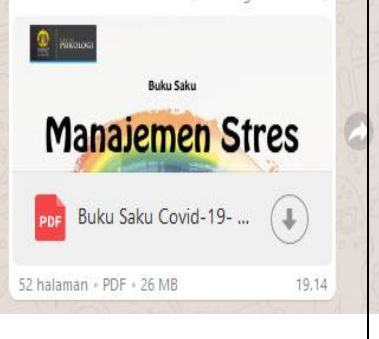 & $\begin{array}{l}\text { Maintenance of } \\
\text { mental health } \\
\text { conditions }\end{array}$ \\
\hline 6. & $\begin{array}{l}\text { Sharing dialogue and } \\
\text { problem-solving } \\
\text { related to the sense of } \\
\text { security of residents in } \\
\text { the PSBB situation. } \\
\text { For example, the } \\
\text { decision to install a } \\
\text { portal to maintain the } \\
\text { safety and health of } \\
\text { residents, reduce } \\
\text { vehicle traffic, provide } \\
\text { sanitation equipment } \\
\text { and others. }\end{array}$ & $\begin{array}{l}\text { For problem-solving } \\
\text { to the problems } \\
\text { encountered }\end{array}$ & 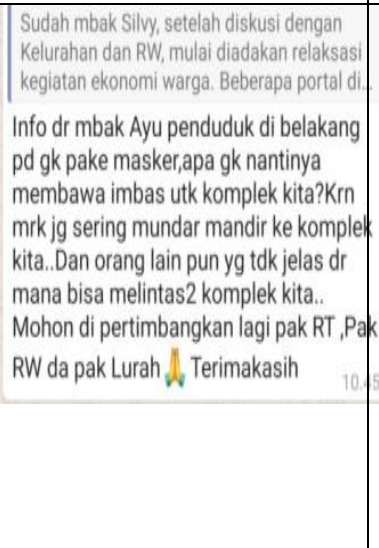 & Citizen safety \\
\hline
\end{tabular}

In the dynamics of communication, WhatsApp messages show a dynamic change from the themes of concern that are built. In the communication process through WhatsApp, there are few dynamics of differences of opinion on a particular issue that opens up a common space for making joint decisions. The author summarises the four themes of concern found in this study: health, maintaining mental health, social assistance, and citizen safety. Thus, the dynamics of citizen communication through WhatsApp groups raises a shared concern (domain of common sense) towards others in difficult times, which is very important in social life.

The key informant explained that the obstacle in participatory communication through WhatsApp media was that there were residents who lived in the neighbourhood association areas but did not have a DKI Jakarta ID card or were outside the neighbourhood association 01 areas. In particular, relatives and boarding house residents often went out or travelled without reporting the boarding house owner or the neighbourhood association. Moreover, they do not join the residents' WhatsApp group. Then, the next obstacle is stall workers and construction workers whose exact numbers and origins are unclear, including their working hours. This condition makes it difficult to collect data, especially regarding health conditions. So, in this situation, communication of citizen participation is very much needed on a reciprocal basis. 
In participatory communication that occurs through WhatsApp group media, the use of a participatory approach allows all the problems faced to become common problems, especially concerning the Covid19 pandemic. That way, ways of solving it can be reached by means of joint deliberation to find solutions. Communication activities that occur in the virtual public space of this WhatsApp group allow everyone to be able to access information about various things, primarily related to the prevention of the Covid-19 virus, through an equal open dialogue. Furthermore, WhatsApp's virtual public space allows the exchange of various important information regarding the development of the Covid-19 virus and public opinions that are offered freely and openly to find solutions to problems faced by residents. In this WhatsApp medium, the Public Space becomes an arena for residents to tell stories and express feelings related to the development of the virus and its effects and the various activities they carry out. As a result, residents obtained various positive aspects of WhatsApp groups at the neighbourhood association level, including ease of interaction and communication, WhatsApp media as a fast medium in conveying information so that it is easily absorbed, residents have the same opportunity to access information related to the development of the Coronavirus and how to anticipate it.

Figure 3. Research Results Framework

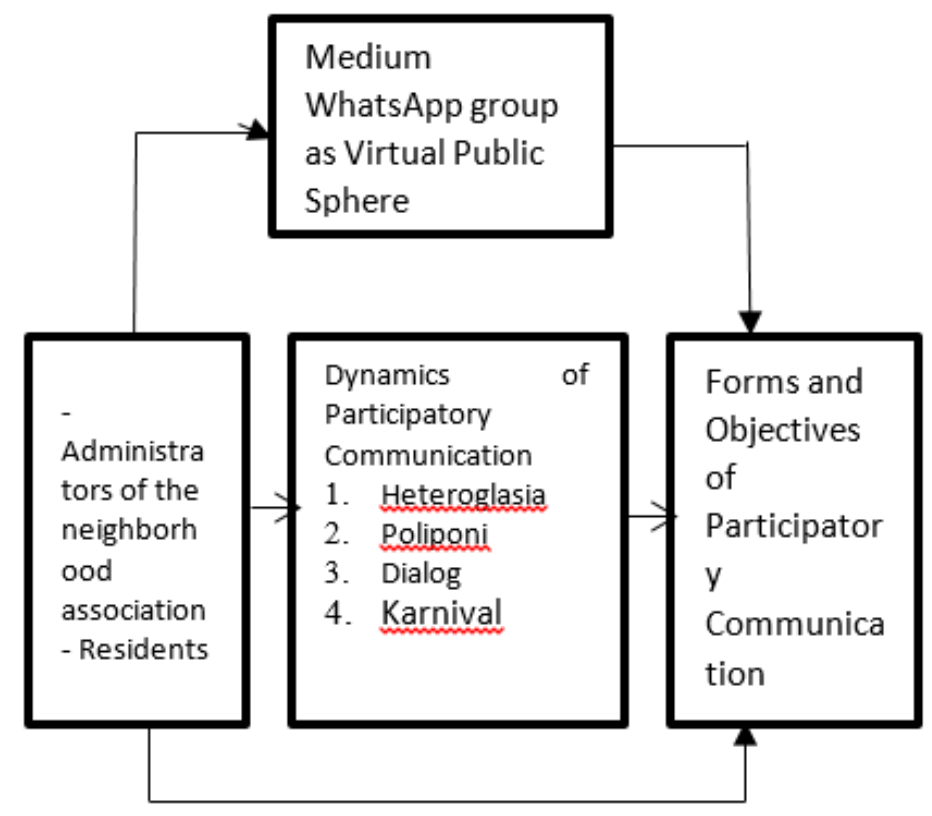

The study results show that participatory communication at the neighbourhood association level must be carried out to anticipate the dangers of Covid19. This is done considering that the neighbourhood association is at the forefront of preventing the spread of the virus at the community level. Communication is carried out, of course, by involving all residents who at the same time use WhatsApp as a communication medium. 
Furthermore, WhatsApp media has become a vast public sphere. Culturally, in this public space, a new culture of democratisation has been born. WhatsApp has become an egalitarian space, and a means for various purposes in common life, especially to solve common problems around anticipating the dangers of Covid19. The public space opens a common concern (domain of common concern) on virus problems. It opens communication spaces in the form of concern for residents' health, concern for mental conditions during a pandemic, care through community social assistance, and concern for residents' security conditions. Thus, this research provides theoretical implications on the contribution of public space in social media that bridges the occurrence of participatory communication. In line with the author's criticism of participatory communication, that in supporting health development, it is carried out by participatory communication with a bottom-up approach and a focus on micro-development.

For this reason, the author believes that it is urgent to develop participatory communication in the "sharing process" of communication carried out through multiplatform media and convergence. Thus, participatory communication must be integrated with "converged communication" based on communication and information technology with all multi-platform channels. Thus the results of this study provide their own challenges in communication science. However, in practical implications, the research results can contribute to knowledge for the wider community because WhatsApp media creates a living space that is able to have a positive impact on social life.

\section{CONCLUSION}

Communal participatory communication to prevent Covid-19 shows the diversity of groups in WhatsApp groups. There are various kinds of differences in terms of age, occupation, culture, and others. This difference is the basis of the four elements or indicators of participatory communication, namely heteroglossia, dialogic, polyphony and carnival. The communication dynamics have one common goal: to carry out health development in the neighbourhood association area of the Pasar Minggu MOH Complex on an ongoing basis. Another goal is to eliminate or reduce communication barriers that occur so that efforts to anticipate the dangers of the spread of Covid-19 can be achieved. Residents can express opinions in WhatsApp's virtual public space, as stated by Habermas. Group participants participate in interactions by asking questions, expressing opinions and complaints, and finding solutions together. Finally, the solutions found are carried out collectively to strengthen each other and continuously strengthen the shared sense of concern (domain of common concern). This action is taken so that residents are aware of the social situation around them, especially those related to the development and prevention of the spread of the Covid-19 virus based on the health protocol that has been set. Thus, the results of this study significantly open the discourse of convergencebased participatory communication, which will open a wider public space for Indonesia's development in all fields that are beneficial to the social life of the community. 


\section{REFERENCES}

Bafadhal, O. M. (2017). Studi Konsumsi Berita Lewat Group Whatsapp. Jurnal Komunikasi Indonesia, V, 49-56. http://www.jke.feb.ui.ac.id/index.php/jkmi/article/view/8628

Citra, S. (2018). 5 Alasan Kenapa Orang Indonesia, Mungkin Juga Seluruh Dunia Jatuh Cinta Pada WhatsApp di Banding Media Chat Lainnya. https://www.hipwee.com/opini/5-alasankenapa-orang-indonesia-mungkinjugaseluruh-dunia-jatuh-cinta-pada-whatsappdi-banding-media-chat-lainnya/

Dewi, M., \& Nulul, N. A. (2018). Komunikasi Partisipatif Masyarakat Industri dalam Mendukung Branding Kota Madiun. Jurnal ILMU KOMUNIKASI, 15(1), 75-90. https://doi.org/10.24002/jik.v15i1.1340

Far Far, R. A. (2011). Komunikasi partisipatif dalam pelaksanaan prima tani di Kecamatan Kakap Kabupaten Pontianak. Agrikan: Jurnal Agribisnis Perikanan, 4(1), 37. https://doi.org/10.29239/j.agrikan.4.1.37-41

Imam, G. (2013). Metode Penelitian Kualitatif Teori dan Praktik. In Jakarta: Bumi Aksara. Jati, W. R. (2016). Cyberspace, Internet, dan Ruang Publik Baru: Aktivisme Online Politik Kelas Menengah Indonesia. Jurnal Pemikiran Sosiologi, 3(1), 25. https://doi.org/10.22146/jps.v3i1.23524

Kartikawati, D. Rajagukguk, D L, Sriwartini, Y. (2019). Strategi Komunikasi Pendidikan Multikultural di Sekolah Inklusi. CV Lentera Kata Demak Jawa Tengah.

Kementerian Kesehatan. (2020). Infeksi Emerging Kementerian Kesehatan RI - Situasi Terkini Perkembangan Novel Coronavirus (2019-nCoV) 10 Februari 2020. Kemenkes RI. https://covid19.kemkes.go.id/situasi-infeksi-emerging/situasi-terkiniperkembangan-novel-coronavirus-2019-ncov-10-februari-2020/

Malka, V., Ariel, Y., \& Avidar, R. (2015). Fighting, worrying and sharing: Operation "Protective Edge" as the first WhatsApp war. In Media, War and Conflict, 8(3), 329344. https://doi.org/10.1177/1750635215611610

Murwani, E. (2017). Literasi Budaya Partisipatif Penggunaan Media Baru pada Siswa SMA di DKI Jakarta. Jurnal IImu Komunikasi, 15(1), 48-59. https://doi.org/10.31315/jik.v15i1.2154

Permendagri. (2017). Permendagri Nomor 2 Tahun 2017. 13-14.

Prasutomo, E., Wijaya, H., \& Weismann, I. T. J. (2019). The Role of Public Sphere According to Jurgen Habermas's Perspective for Multicultural Societies in the Indonesian Context. FUADUNA : Jurnal Kajian Keagamaan Dan Kemasyarakatan, 3(2), 79. https://doi.org/10.30983/fuaduna.v3i2.2548

Pujihartati, H. S., \& Wijaya, M. (2019). Dinamika Kelompok Sosial, 8(1), 121-130.

Rahartri. (2019). Media Komunikasi Efektif pada Layanan Jasa Informasi: Studi Kasus di Kawasan Pusat Penelitian IImu Pengetahuan dan Teknologi (Puspiptek). Pustakawan, 26(2), 109-117.

Shery Arstein. (2013). Pengaruh Lama Tinggal dalam Pengelolaan Lingkungan Permukiman. Journal ComTech BINUS, 4(1), 24-32.

Sinaga, D., Winoto, Y., \& Perdana, F. (2016). Membangun Komunikasi Partisipatif Masyarakat Upaya MelestarikanTanaman Salak Lokal di Manonjaya Tasikmalaya. Jurnal Kajian Informasi Dan Perpustakaan, 4(2), 191. https://doi.org/10.24198/jkip.v4i2.10174

Soleha, F. (2017). Komunikasi Partisipatif Pada Program Pos Pembinaan Terpadu (Studi 
Kasus Di Kelurahan Jawa, Kecamatan Samarinda Ulu, Kota Samarinda),. EJournal Ilmu Komunikasi, 5(2), 110-123.

Sugiyono. (2007). Metode Penelitian Kualitatif R dan D. Bandung Alfabeta.

Sutowo, I. R. (2020). Komunikasi partisipatif dalam pengembangan kewirausahaan sosial di pandeglang, banten. Expose: Jurnal IImu Komunikasi, 3(1), 21. https://doi.org/10.33021/exp.v3i1.885

Syahyuti. (2006). 30 konsep penting dalam pembangunan pedesaan dan pertanian. Bina Rena Pariwara; Indonesia: Bina Rena Pariwara. https://openlibrary.org/books/OL21095462M/30_konsep_penting_dalam_pemban gunan_pedesaan_dan_pertanian

Widyawati, K., Ernawati, A., \& Puspita Dewi, F. (2011). Peranan Ruang Terbuka Publik terhadap Tingkat Solidaritas dan Kepedulian Penghuni Kawasan Perumahan di Jakarta. Jurnal Ilmiah Faktor Exacta, 4(3), 246-260. DOI: http://dx.doi.org/10.30998/faktorexacta.v4i3.54 